\title{
AEROBIC TRAINING IN OBESE ADOLESCENTS: A MULTIDISCIPLINARY APPROACH
}

\author{
TREINAMENTO AERÓBIO EM ADOLESCENTES OBESOS: UMA ABORDAGEM MULTIDISCIPLINAR
}

ORIGAL ARTICLE

ENTRENAMIENTO AERÓBICO EN OBESOS ADOLESCENTES: UN ENFOQUE MULTIDISCIPLINARIO

Original Article

ARTIGO ORIGINAL

Artículo Original

\begin{abstract}
Priscyla Praxedes Gomes ${ }^{1}$ (Physical Education Professional)

Mara Cristina Lofrano-Prado 2

(Psychologist)

Camila Tenório Calazans de Lira' (Physical Education Professional)

Thiago Ricardo dos Santos Tenório (Physical Education Professional)

João Paulo Botero ${ }^{3}$

(Physical Education Professional)

Marcos André Moura dos Santos ${ }^{1}$ (Physical Education Professional)

Wagner Luiz do Prado 3

(Physical Education Professional)
\end{abstract}

1. Universidade de Pernambuco, Escola Superior de Educação Física, Associated Program of Graduate Studies in Physical Education (UPE/UFPB), Recife, PE, Brazil. 2. Universidade de São Paulo, Neuroscience and Behavior Graduate Program, São Paulo, SP, Brazil. 3. Universidade Federal de São Paulo, Human Movement Science and Rehabiliation Graduate Programa Unifesp, São Paulo, SP, Brazil.

\section{Correspondence:}

Marcos André Moura dos Santos. Escola Superior de Educação Física Universidade de Pernambuco, Rua Arnóbio Marques, 310, Santo Amaro, Recife, Brasil. 50100-130.mmoura23@gmail.com

\begin{abstract}
Introduction: The prevalence of excess weight/obesity in adolescence has increased, and physical training may be effective in combating this scenario. Objective: To analyze the effect of different intensities of aerobic training on the body composition of obese adolescents undergoing multidisciplinary intervention. Methods: In this study, 107 pubertal (Tanner 3 and 4$)$, obese $\left(B M I=34.72 \pm 4.10 \mathrm{~kg} / \mathrm{m}^{2}\right)$ adolescents $(14.85 \pm 1.44$ years) were randomly assigned to three groups: high intensity training (HITG - ventilatory threshold I (VTI)); low intensity training (LITG - 20\% below the VTI) and control group (CG), without intervention. The adolescents in the HITG and LITG underwent nutritional and psychological (1x/week) and clinical (1 $\mathrm{x} /$ month) follow-up and physical training ( $3 x /$ week) for 12 weeks. Results: Reductions in fat mass ( $F M)$ and body fat percentage (BFP) $(p<0.001)$ and an increase in fat-free mass (FFM) $(p<0.001)$ were observed in all groups. There was a reduction in BMI only in the experimental groups $(p<0.001)$. Conclusion: The effects of multidisciplinary treatment on the body composition of obese adolescents occur independently of the intensity of aerobic physical training. Level of Evidence l; High quality randomized clinical studies with or without statistically significant difference, but with narrow confidence intervals.
\end{abstract}

Keywords: Obesity; Aerobic Exercise; Adipose tissue; Muscle Tissue; Adolescent.

\section{RESUMO}

Introdução: A prevalência de sobrepeso / obesidade na adolescência aumentou, e treinamento físico pode ser eficaz para combater este cenário. Objetivo: Analisar o efeito de diferentes intensidades de treinamento aeróbio sobre a composição corporal de adolescentes obesos, submetidos à intervenção multidisciplinar. Métodos: Neste estudo, 107 adolescentes (14,85 1,44 anos), púberes (Tanner 3 e 4) e obesos $\left(34,72 \pm 4,10 \mathrm{~kg} / \mathrm{m}^{2}\right)$ foram aleatoriamente alocados em três grupos: treinamento de alta intensidade (GTAI - limiar ventilatório I (LVI)), treinamento de baixa intensidade (GTBI-20\% abaixo do LVI) e grupo controle (GC), sem intervenção. Os adolescentes do GTAl e GTBI receberam acompanhamento nutricional e psicológico (1X/semana), clínico (1X/mês) e treinamento físico (3x/semana) durante 12 semanas. Resultados: Foram observadas reduções na massa gorda (MG) e no percentual de gordura (\%G) em todos os grupos $(p<0,001)$ e um aumento na massa livre de gordura (MLG) $(p<0,001)$. Houve redução no IMC apenas nos grupos experimentais $(p<0,001)$. Conclusão: Os efeitos do tratamento multidisciplinar sobre a composição corporal de adolescentes obesos ocorrem independentes da intensidade do treinamento físico aeróbio. Nível de Evidência l; Estudos clínicos randomizado de alta qualidade com ou sem diferença estatisticamente significante, mas com intervalos de confiança estreitos.

Descritores: Obesidade; Exercício Aeróbio; Tecido adiposo; Tecido Muscular; Adolescente.

\section{RESUMEN}

Introducción: La prevalencia de sobrepeso / obesidad en la adolescencia aumentó, y el entrenamiento físico puede ser eficaz para combatir este escenario. Objetivo: Analizar el efecto de diferentes intensidades de entrenamiento aeróbico sobre la composición corporal de adolescentes obesos sometidos a la intervención multidisciplinaria. Métodos: En este estudio, 107 adolescentes (14,85 \pm 1,44 años), púberes (Tanner 3 y 4), obesos $\left(34,72 \pm 4,10 \mathrm{~kg} / \mathrm{m}^{2}\right.$ ) fueron aleatoriamente asignados en tres grupos: entrenamiento de alta intensidad (GEAl - umbral de ventilación I (LVI)); El entrenamiento de baja intensidad (GEBI - 20\% por debajo del LVI) y el grupo de control (GC), sin intervención. Los adolescentes del GEAl y GEBI recibieron seguimiento nutricional y psicológico (1x/semana), clínico (1x/mes) y entrenamiento físico ( $3 x /$ semana) durante 12 semanas. Resultados: Se observaron reducciones en la masa grasa $(M G)$ y en el porcentaje de grasa (\% $G$ ) en todos los grupos $(p<0,001)$ y un aumento en la masa libre de grasa (MLG) $(p<0,001)$. Se observó una reducción en el IMC sólo en los grupos experimentales $(p<0,001)$. Conclusión: Los efectos del tratamiento multidisciplinario sobre la composición corporal de adolescentes obesos ocurren independientes de la intensidad del entrenamiento físico aeróbico. Nivel de Evidencia l; Estudio clínico aleatorio de alta calidad, con o sin diferencia estadísticamente significativa, pero con estrechos intervalos de confianza.

Descriptores: Obesidad; Ejercicio Aeróbico; Tejido Adiposo; tejido muscular; Adolescente. 


\section{INTRODUCTION}

The prevalence of overweight and obesity among children and adolescents around the world is estimated at 21.4\% for girls and $22.9 \%$ for boys. ${ }^{1,2}$ In Brazil, this picture becomes more aggravating, where the prevalence is around $37.5 \%$ boys and $33.9 \%$ in girls and varying between regions of the country, and the South the most prevalent., In this scenario, body composition (CC) during adolescence has been described as a predictor of body mass in adulthood and some of its components (fat mass) are associated with risk factors for developing cardiovascular disease, diabetes mellitus, osteoporosis, colon cancer , breast and uterus. ${ }^{5,6}$

In a multidisciplinary context, aerobic exercise training has been an effective and safe feature in the management of obesity and metabolic risks. ${ }^{7,8}$ It is known that aerobic exercise training induces major adjustments in the obese body, such as reducing fat, total body mass, increased cardiorespiratory fitness and metabolic control. However, such adjustments appear to be dependent on the intensity of the physical effort is realized. In adolescents, the results of earlier studies seem contradictory both one and don't have a consensus, as some report better results in response to exercise in low-intensity, ${ }^{9,10}$ others at high intensity, ${ }^{11}$ beyond reporting no difference between the intensities in the final outcome variable. ${ }^{8,12}$

Despite the recognition of the effects of exposure to physical training, there is a gap that evidences the effects of aerobic training performed in a multidisciplinary context in obese adolescents. Thus, the objective of this study is to analyze the effects of different intensities of aerobic training on the body composition of obese adolescents submitted to multidisciplinary intervention.

\section{METHODS}

\section{Experimental lineation of the study}

\section{Sample}

The sample consisted of adolescents of both sexes, recruited through advertisements in the media (newspaper, magazines, radio and television) of the city of Recife and metropolitan region. Due to the voluntary adherence and the characteristics of the study, It wasn't made a sample calculation "a priore", but "a posteriore", after the analysis, it was calculated and in all cases was higher than 0.88 ( $G$ * Power 3.1).

In the present study, it was included adolescents (13 to 18 years of age), pubescent (stages 3 and 4) according to criteria proposed by Tanner $(1976)^{13}$, and obese (BMI> P95th) according to the criteria of the Centers for Disease Control and Prevention (CDC) ${ }^{14}$. The exclusion criteria were: body mass above $120 \mathrm{~kg}$ (equipment limitation); genetic, metabolic or endocrine diseases (self reported or identified by the endocrinologist); electrocardiographic changes at rest; chronic alcohol consumption; prior use of drugs and pregnancy during the intervention.

A total of 276 adolescents volunteered to participate in the study. Anthropometric measurements and maturational stage evaluation were performed at the first visit. At this stage, 169 adolescents didn't meet the inclusion criteria. The adolescents underwent medical examinations and electrocardiogram (ECG) of rest and effort. The final sample consisted of 107 subjects (63 girls). In the baseline analyzes, anthropometric measurements of CC and blood collections were performed.

In the allocation of the groups, initially all the participants were submitted to an individual and confidential semi-structured interview to verify the motivation to participate in a program for long-term weight loss. The interview consisted of eight questions aimed at evaluating personal reasons for the treatment of weight loss and the barriers faced in this process, performed by a psychologist with time of 20 minutes, previously described. ${ }^{15}$
Em seguida, os participantes foram divididos intencionalmente no grupo controle (GC, $n=45$, adolescentes com menor motivação intrínseca) ou grupo experimental ( $n=62$, adolescentes com maior motivação intrínseca); b) os participantes do grupo experimental foram posteriormente randomizados (WWW.randomizer.org) em dois subgrupos: treinamento de alta intensidade (GTAl; $\mathrm{n}=31)$ e treinamento de baixa intensidade (GTBI; $n=31$ ). Os participantes não tinham conhecimento quanto à alocação nos grupos experimentais. The adolescents belonging to GTAI and GTBI also received nutritional counseling, psychological and clinical follow-up for 12 weeks (Figure 1). The CG adolescents were also offered the possibility of receiving the same intervention after the end of the experiment (time delay control). The study was approved by the Ethics Committee of the University of Pernambuco (CAAE: 15798113.9.0000.5207) and the Free and Informed Consent was obtained from the participants and parents and/or legal responsible.

\section{Procedures}

Data were collected by the Group's team of Research in Nutrition and Exercise (GENE), University of Pernambuco, properly trained. All adolescents performed the same battery of tests under the same conditions, whenever possible, by the same person and the same time of day tominimize circadian influences on the results. The evaluations were conducted before the start of the study (baseline) and after 12 weeks. Adolescents were asked to appear in two days at the research laboratory. At the first meeting the interviews were conducted, filling out the forms and clarification of the study procedures. At the second meeting, anthropometric evaluations were conducted, body composition and cardiorespiratory fitness.

\section{Anthropometry and Body Composition}

For to determine body mass and height, a portable scale (Tanita, Brazil) and a stadiometer with a precision of $0.1 \mathrm{~cm}$ were used. The body mass index (BMI) was determined by dividing the body mass (kg) by the square of the height $\left(\mathrm{m}^{2}\right)$. Body composition (DXA) was performed with HOLOGIC QDR WI equipment model (Malborough, MA, USA) with radiation dose below 1.0 mRem. All scans were analyzed by a specialized investigator and trained for this purpose. The method calculates the $\mathrm{CC}$ by dividing the body into anatomical regions, and the results presented by the total parameters are expressed in grams of fat mass $(\mathrm{MG})$, percentage of $(\% \mathrm{G})$ and regional parameters, such as arms and legs, gynoid region and android region. After the scanning, the limbs were demarcated and separated from the trunk and head by lines determined by the equipment itself. The lines were adjusted using specific anatomical points determined by the manufacturer. From these data, it was estimated the appendicular thin tissue (TMA) determined by the sum of the soft thin tissue of the upper and lower, right and left limbs, and the central adipose tissue (TAC) through the trunk fat. ${ }^{16}$

\section{Ergospirometry}

The respiratory variables were obtained by the method of measurement of respiratory gas exchange through the Quark PFT Ergo ${ }^{\circledR}$ gas analyzer (Cosmed, Italy). We used a protocol with fixed increments speed of $1 \mathrm{~km} / \mathrm{h}$ every minute, with an initial charge three minutes at $4 \mathrm{~km} / \mathrm{h}$. The test interruption criteria were volitional fatigue or respiratory coefficient above 1.1.17 The LVI was determined by visual inspection of the respiratory curves by two independent investigators, identified as the breakpoint linearity between carbon dioxide production $\left(\mathrm{CO}_{2}\right)$ and oxygen consumption $\left(\mathrm{VO}_{2}\right)$ ( $\mathrm{V}$-slope) at which point, the curve of oxygen ventilatory equivalent $\left(\mathrm{VE} / \mathrm{NO}_{2}\right)$ and fraction exhaled $\mathrm{CO}_{2}\left(\mathrm{PETCO}_{2}\right)$ have reached their lowest values immediately before the rising equivalents. ${ }^{17}$ There monitoring the heart rate (HR) during the entire test. 


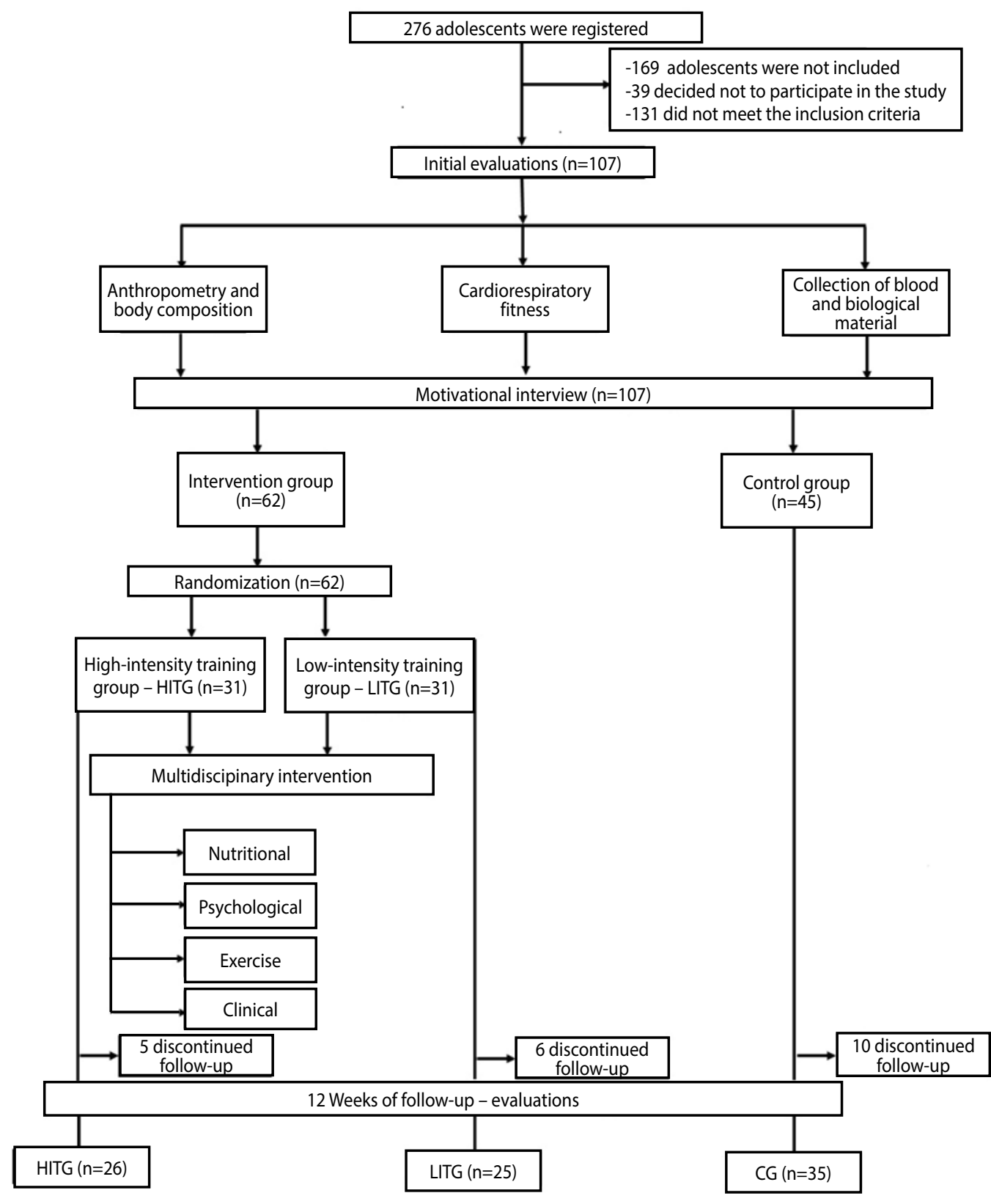

Figure 1. Study flowchart.

\section{Nutritional, Psychological and Clinical Intervention}

The nutritional intervention consisted of group meetings $(\approx 10$ adolescents per group) once a week with duration of one hour each and They were designed and supervised by a nutritionist. At the meetings, topics such as fast food, food labels, types of fat, diet products and light, and strategies for special occasions (holidays and anniversaries) were addressed. No diets participants were prescribed.

Psychological intervention was performed in groups $(\approx 10$ adolescents per group) once a week, an hour each session. The issues were worked: emotions (feelings), self-esteem, body image, prejudice, eating disorders, behavioral problems, family issues, among others. The psychologist was available to volunteers to support and care if necessary.

Individualized clinical follow-up was carried out once a month. In the consultations, the endocrinologist measured the blood pressure and made monitoring the clinical course of the volunteers, in order to facilitate adherence to the rules of study in general. There was no prescription of any drug that in any way could interfere with or modulate the results.

\section{Physical training}

The teenagers performed three weekly sessions of aerobic exercise in group (10 teens), held in motorized treadmill (Ergolife ${ }^{\circledR}$ ) maintained at $1 \%$ gradient over 12 weeks, with energy expenditure set at $350 \mathrm{kcal} / \mathrm{session}(1,050 \mathrm{kcal} /$ week). The intervention was performed in the Biodynamics Laboratory of UPE/ESEF and accompanied by researchers and academics of the course of Physical Education. The LRT trained on the ventilatory threshold corresponding intensity I (LVI) and GTBI trained in intensity corresponding to 20\% below LVI. The intensity of the physical training was individualized based on ventilatory threshold 1 (LV1). To ensure that the preset energy expenditure was reached, the length of each section was determined considering that for each liter of oxygen consumed (VO2 L / min) $4.96 \mathrm{kcal}$ of energy was released, based on the metabolic equivalent task (MET), where: Duration of the exercise session $(\mathrm{min})=350 \mathrm{kcal} /$ ( VO2 ( $\mathrm{L} / \mathrm{min}$ ) in charge $1 \mathrm{MET}$ ) where: $\mathrm{VO}_{2}=$ oxygen consumption; $\mathrm{MET}=$ metabolic equivalent of task. ${ }^{18,19}$ 


\section{Statistical analysis}

The normality and homogeneity of data variavel were analyzed using the Kolmogorov-Smirnov and Levene test, respectively. Data are expressed as mean and standard deviation. For comparison between groups at the baseline it was as used the ANOVA one-way, followed by Fisher's Post-Hoc test. In the comparisons between the groups (GC, GTBI e GTAl) and moments (baseline and 12 weeks), between the groups (GC, GTBI and GTAI) and moments (baseline and 12 weeks), it was used the Variance analysis of two ways (ANOVA two-way), with Post-hoc Fisher. In addition, ir was calculated the effect size of the interventions by comparing it with the GC (Cohen's $d$ ). The level of significance was set at $p<0.05$. The Statistica program, version 7.0, was used in the data analysis.

\section{RESULTS}

Table 1 presents the descriptive characteristics and baseline comparisons. No differences were observed between groups in the different variables studied. Although the energy expenditure was similar between GTAl and GTBI ( $350 \mathrm{kcal})$, the GTAl obtained a lower daily training volume (38.4 $\pm 4.3 \mathrm{~min}$.) when compared to GTBI $(52.3 \pm 6.5 \mathrm{~min}$.) $(p=0.036)$. At the end of 12 weeks of intervention, there was an adherence to the study time, being $83.8 \%$ in GTAl, $80.6 \%$ in GTBI and $77.7 \%$ in $\mathrm{CG}$.

Table 2 presents the results of the multidisciplinary intervention on anthropometric and CC variables. These changes occurred differently in each parameter analyzed. In all groups, changes due to the physical growth process, duly confirmed by the significance conditioned to the time factor $(P<0.001)$, reinforced by the interaction (i.e., group $\mathrm{x}$ time) were significant in the anthropometric variables $(P<0,05)$. No significant change in body mass $(M C)$ was observed in any of the groups. In IMC, ir was observed a GTAI and GTBI reduction (time factor; $P<0.001$ ), but there was no significant change in GC. In the CC parameters, there was a reduction of $\% \mathrm{G}$ and $M G$ and an increase in $M L G$ (time factor; $P<0.001$ ); these responses were observed in all groups. The effect size of the variables ranged from "medium" to "very high", being: \%G (GTAI $(d)=1,19$ e GTBI $(d)=1,47) ; \mathrm{MG}(\mathrm{GTAl}$ $(d)=0,61$ e GTBI $(d)=0,94)$; and increase in MLG (GTAI $(d)=0,95$ and $\mathrm{GTBI}(d)=0,58)$.

Table 3 presents the results of the intervention on the regional parameters of body fat. Significant changes were found in all analyzed parameters. It was verify that in all variables significant changes were

Table 1. Descriptive characteristics of obese adolescents submitted to multidisciplinary intervention.

\begin{tabular}{|c|c|c|c|c|}
\hline & $\mathrm{GC}(\mathrm{N}=35)$ & GTAI (N=26) & GTBI (N=25) & $\mathrm{P}$ \\
\hline Age (years) & $14,61 \pm 1,38$ & $15,01 \pm 1,46$ & $15,03 \pm 1,52$ & 0,35 \\
\hline Height (m) & $1,64 \pm 0,07$ & $1,65 \pm 0,07$ & $1,66 \pm 0,06$ & 0,49 \\
\hline$M C(\mathrm{~kg})$ & $93,47 \pm 14,48$ & $93,91 \pm 14,15$ & $98,33 \pm 12,56$ & 0,28 \\
\hline IMC $\left(\mathrm{kg}^{-1} / \mathrm{m}^{2}\right)$ & $34,52 \pm 3,97$ & $34,10 \pm 3,85$ & $35,64 \pm 4,48$ & 0,31 \\
\hline MLG $(\mathrm{kg})$ & $43,38 \pm 7,27$ & $44,64 \pm 8,32$ & $45,32 \pm 6,88$ & 0,52 \\
\hline$\% G$ & $50,45 \pm 5,01$ & $49,52 \pm 4,43$ & $50,96 \pm 5,09$ & 0,50 \\
\hline TAC (kg) & $23,74 \pm 5,64$ & $24,41 \pm 5,03$ & $21,49 \pm 4,26$ & 0,13 \\
\hline TAC (\%) & $53,86 \pm 5,62$ & $54,03 \pm 5,11$ & $51,95 \pm 4,43$ & 0,23 \\
\hline MLGTr (kg) & $19,36 \pm 3,84$ & $20,12 \pm 3,69$ & $19,24 \pm 3,85$ & 0,57 \\
\hline MGA (kg) & $3,80 \pm 0,97$ & $3,99 \pm 0,86$ & $3,41 \pm 0,85$ & 0,59 \\
\hline MGA (\%) & $54,34 \pm 5,44$ & $54,28 \pm 4,10$ & $52,96 \pm 3,86$ & 0,61 \\
\hline MGG (KG) & $7,33 \pm 1,56$ & $7,63 \pm 1,88$ & $6,96 \pm 1,49$ & 0,45 \\
\hline MGG (\%) & $50,89 \pm 6,08$ & $50,94 \pm 6,00$ & $50,36 \pm 4,75$ & 0,54 \\
\hline TMMA (kg) & $21,70 \pm 7,54$ & $20,81 \pm 3,36$ & $20,77 \pm 4,3$ & 0,74 \\
\hline
\end{tabular}

$\mathrm{GC}=$ Control Group; GTAI = High Intensity Training Group; GTBI = Low Intensity Training Group; MC= Body Mass; $I M C=$ Body Mass Index; MLG= Fat Free Mass; \%G = fat percentage; TAC = Central Adipose Tissue; MLGTr= Trunk fat free mass; MGA= android fat mass; MGG= Gynoid Fat Mass; TMMA= Mole appendicular lean tissue. ${ }^{*} \mathrm{P}<0,005$.
Tabla 2. Effects of different intensities of aerobic training on body composition in obese adolescents submitted to 12 weeks of multidisciplinary intervention.

\begin{tabular}{c|c|c|c|c|c}
\hline & & & & ANOVA & \\
\hline & Basal & $\mathbf{1 2}$ WEEKS & G & T & GxT \\
\hline HEIGHT (m) & & & & & \\
\hline GC & $1,64 \pm 0,08$ & $1,65 \pm 0,08^{*}$ & & & \\
\hline GTAI & $1,66 \pm 0,06$ & $1,69 \pm 0,06^{*}$ & 0,363 & $<0,001$ & $<0,001$ \\
\hline GTBI & $1,65 \pm 0,07$ & $1,67 \pm 0,07^{*}$ & & & \\
\hline MC (Kg) & & & & & \\
\hline GC & $95,63 \pm 14,72$ & $96,55 \pm 14,95$ & & & \\
\hline GTAI & $98,36 \pm 13,24$ & $97,22 \pm 13,41$ & 0,571 & 0,640 & 0,026 \\
\hline GTBI & $93,70 \pm 15,00$ & $93,48 \pm 14,09$ & & & \\
\hline IMC (Kg/m $\left.\mathbf{m}^{2}\right)$ & & & & & \\
\hline GC & $35,09 \pm 4,11$ & $35,17 \pm 4,33$ & & & \\
\hline GTAI & $35,36 \pm 4,78$ & $34,12 \pm 5,08^{*}$ & 0,415 & $<0,001$ & $<0,001$ \\
\hline GTBI & $34,07 \pm 4,05$ & $33,23 \pm 4,07^{*}$ & & & \\
\hline MG (kg) & & & & & \\
\hline GC & $47,86 \pm 9,55$ & $41,41 \pm 9,14^{*}$ & & & \\
\hline GTAI & $49,37 \pm 8,98$ & $42,13 \pm 9,74^{*}$ & 0,348 & $<0,001$ & 0,280 \\
\hline GTBI & $45,04 \pm 7,25$ & $39,61 \pm 8,06^{*}$ & & & \\
\hline MLG (kg) & & & & & \\
\hline GC & $44,32 \pm 6,95$ & $50,87 \pm 9,14^{*}$ & & & \\
\hline GTAI & $45,52 \pm 6,87$ & $50,71 \pm 6,77^{*}$ & 0,780 & $<0,001$ & 0,130 \\
\hline GTBI & $44,54 \pm 8,70$ & $48,67 \pm 8,61^{*}$ & & & \\
\hline \%G & & & & & \\
\hline GC & $50,67 \pm 5,33$ & $43,86 \pm 6,21^{*}$ & & & \\
\hline GTAI & $50,74 \pm 4,92$ & $44,07 \pm 6,12^{*}$ & 0,734 & $<0,001$ & 0,836 \\
\hline GTBI & $49,53 \pm 4,24$ & $43,17 \pm 5,50^{*}$ & & & \\
\hline
\end{tabular}

GTAI = High Intensity Training Group; GTBI = Low Intensity Training Group; CG = Control Group; MS = Body Mass; $\mathrm{BMI}=$ body mass index; $\mathrm{MG}=$ Fat Mass; $\mathrm{MLM}=$ Fat Free Mass; \%G = Fat Percentage; $\mathrm{G}$ = factor group; $\mathrm{T}=$ time factor; $\mathrm{GxT}=$ interaction; * $\mathrm{p}<0,005 ; \mathrm{G}=$ factor group; $\mathrm{T}=$ time factor; $\mathrm{GXT}=$ group/time interaction factor.

Table 3. Effects of different intensities of aerobic training on regional parameters of body composition in obese adolescents submitted to 12 weeks of multidisciplinary intervention.

\begin{tabular}{c|c|c|c|c|c}
\hline & & & & ANOVA & \\
\hline & Basal & $\mathbf{1 2}$ WEEKS & G & T & GxT \\
\hline TAC (kg) & & & & & \\
\hline GC & $23,74 \pm 5,64$ & $20,34 \pm 4,81^{*}$ & & & \\
\hline GTAI & $24,41 \pm 5,03$ & $20,66 \pm 5,54^{*}$ & 0,190 & $<0,001$ & 0,293 \\
\hline GTBI & $21,49 \pm 4,26$ & $18,85 \pm 5,04^{*}$ & & & \\
\hline TAC (\%) & & & & & \\
\hline GC & $53,86 \pm 5,62$ & $45,22 \pm 6,43^{*}$ & & & \\
\hline GTAI & $54,03 \pm 5,11$ & $45,35 \pm 6,44^{*}$ & 0,412 & $<0,001$ & 0,842 \\
\hline GTBI & $51,95 \pm 4,43$ & $43,85 \pm 6,22^{*}$ & & & \\
\hline MGA (kg) & & & & & \\
\hline GC & $3,80 \pm 0,97$ & $3,41 \pm 0,97^{*}$ & & & \\
\hline GTAI & $3,99 \pm 0,86$ & $3,46 \pm 0,92^{*}$ & 0,116 & $<0,001$ & 0,325 \\
\hline GTBI & $3,41 \pm 0,85$ & $3,02 \pm 0,73^{*}$ & & & \\
\hline MGA (\%) & & & & & \\
\hline GC & $54,34 \pm 5,44$ & $46,41 \pm 6,39^{*}$ & & & \\
\hline GTAI & $54,28 \pm 4,10$ & $47,02 \pm 5,80^{*}$ & 0,540 & $<0,001$ & 0,899 \\
\hline GTBI & $52,96 \pm 3,86$ & $45,43 \pm 5,42^{*}$ & & & \\
\hline MGG (KG) & & & & & \\
\hline GC & $7,33 \pm 1,56$ & $6,67 \pm 1,15^{*}$ & & & \\
\hline GTAI & $7,63 \pm 1,88$ & $6,81 \pm 1,79^{*}$ & 0,412 & $<0,001$ & 0,490 \\
\hline GTBI & $6,96 \pm 1,49$ & $6,35 \pm 1,37^{*}$ & & & \\
\hline MGG (\%) & & & & & \\
\hline GC & $50,89 \pm 6,08$ & $44,05 \pm 6,88^{*}$ & & & \\
\hline GTAI & $50,94 \pm 6,00$ & $44,29 \pm 7,85^{*}$ & 0,872 & $<0,001$ & 0,990 \\
\hline GTBI & $50,36 \pm 4,75$ & $43,61 \pm 6,03^{*}$ & & & \\
\hline TMA (kg) & & & & & \\
\hline GC & $21,70 \pm 7,54$ & $22,97 \pm 4,54^{*}$ & & & \\
\hline GTAI & $20,81 \pm 3,36$ & $24,01 \pm 4,58^{*}$ & 9,959 & $<0,001$ & 0,414 \\
\hline GTBI & $20,77 \pm 4,53$ & $23,39 \pm 4,45^{*}$ & & & \\
\hline C $(1)$ & & & \\
\hline
\end{tabular}

TAC = Central Adipose Tissue (kq e \%); MGA= android fat mass; MGG= Gynoid Fat Mass; TMA= Appendicular Lean Tissue; $G=$ group factor; $T=$ time factor; $G \times T=$ interaction; ${ }^{*} P<0,005 ; G=$ factor group; $T=$ time factor; $G \times T$ group/time interaction factor. 
observed conditioned to the time factor $(P<0,001)$, however, there was no statistically significant difference when the group factor and the interaction ( $G \times T, P>0.05$ ) were observed, demonstrating the effectiveness of the programthat regard to the proposed time and form. The significance of these results expressed by the effect size are between "small" to "very high", like observed in each variable, being: Central adipose tissue (TAC) (Kg): GTAI $(d)=1,31$ and GTBI $(d)=1,69$, relative TAC (\%): GTAI (d) =1,45 and GTBI (d) =1,74, MGA (Kg): GTAI (d) $=0,36$ and GTBI $(d)=0,90$, MGA\%: GTAI $(d)=1,33$ and GTBI $(d)=1,67$, MGG (kg): GTAI (d) =0,32 and GTBI (d) =0,68, MGG (\%) (kg): GTAI (d) $=0,98$ and $\mathrm{GTBI}(\mathrm{d})=1,23$ and appendicular lean tissue (TMA) $(\mathrm{kg})$ : GTAI (d) $=0,37$ and GTBI (d) $=0,35$.

\section{DISCUSSION}

The main finding of the present study was that regardless of the intensity of aerobic training, the multidisciplinary intervention promoted significant changes in the total and regional CC of obese adolescents, even when the energy expenditure between the sessions is matched. Interventions that aim to control CD, especially through reduction of central adiposity, are highly desirable for the treatment and control of risk factors associated with obesity. ${ }^{8,10}$ Changes in CC of obese adolescents submitted to multidisciplinary intervention have been widely

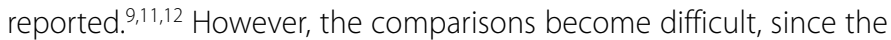
results of the studies don't present a standard for exercise prescription, besides the measurement of CC that presents great difficulty in the face of the limitations of some equipment used. ${ }^{20}$

Nevertheless, studies have reported the need for investigations with the purpose of identifying the effects of physical exercise performed at different intensities on variables related to the health of obese individuals, ${ }^{21}$ such as the lack of literature and studies that indicate which best type, methodology and intensity of physical training for obese children and adolescents. ${ }^{22}$ Anyway, in the present study a high adherence to the proposed program was observed, which guarantees the effects observed in each one of the studied variables. Thus, it is possible to speculate that the multidisciplinary approach seems to be an important strategy in the treatment of obesity in this population.

In normal metabolic conditions, a chronic negative energy balance, induced by reduction in food intake or elevated energy expenditure, leads to a reduction in body mass ${ }^{9}$ and, if the greater the energy deficit, the greater the reduction in body adiposity, that is, in situations in which the caloric deficit is equal, changes in composition will be similar, regardless of the exercise intensity, fact observed in the present study.

It is essential to the health of obese adolescents the reduction of central adiposity, and has previously been shown that aerobic training, even in the absence of reducing total body mass, provides significant reduction in the central fat ${ }^{11}$, duly established in this study. Adult individuals, when subjected to interventions for weight reduction usually have fat mass reduction with concomitant reduction of lean mass ${ }^{23}$, however, in adolescents, reducing body fat, arising interventions with moderate energy deficit, isn't accompanied by a reduction in lean body mass ${ }^{12}$, probably because the adolescence be a highly anabolic phase due to the high concentration of circulating anabolic hormones such as growth hormone $(\mathrm{GH}){ }^{24}$

In this intervention, it was observed that the control group also showed improvements in body shape after 12 weeks of aerobic training.
Significant improvements in the control group isn't a common finding in studies of clinical trials, but can be partly explained by the characteristics, age profile and maturational status of the participants. In a review study conducted by Waters et al. ${ }^{25}$ it was found that an important contribution to changes in the size of the effect in clinical trials studies, with physical activity interventions, is the concomitant increase in physical activity, both for participants in the intervention group and as for the control group, which could have a mediating role the effects of the intervention. This can be caused by several factors, including behavioral changes, changes in lifestyle, in addition to the recruitment of highly motivated volunteers to make up the control group during theintervention. It's possivel highlight that during the period or pubertal stage chosen like the inclusion criterion, the individuals were placed in the same level of maturity, that is, puberty. Thus, changes related to time, may in itself be a factor that causes CC changes of adolescents. ${ }^{26,27}$ Furthermore, during adolescence there is an intense burst of growth (growth spurt in) in height. This peak height velocity occurs on average two years earlier in girls ( $\sim 12$ years) than in boys ( 14 years) and can be a framework of changes in different DC characteristics, independent of exposure to training ${ }^{28}$.

Despite these aspects, previous studies in order to investigate the effects of aerobic isocaloric exercise at different intensities, observed changes on body composition, feeding behavior ${ }^{29}$, improvement in the quality of life of obese adolescents ${ }^{30}$ submitted to the intervention without the inclusion of the control group.

This study has limitations. In particular, the absence of information on food intake and level of physical activity as well as the dosage of some hormones, such as growth hormone $(\mathrm{GH})$, and the non-adjustment of the charges during the intervention period, which would help in explaining results. However, the strong point of this study is that the training intensities were based on anaerobic threshold which is currently considered. The best variable to prescription and control of metabolic overload which the body is subjected, minimizing individual differences commonly observed when the intensity of the effort, is on the $\mathrm{VO}_{2 \max }$.

The present study ratifies previous evidence on the effectiveness of multidisciplinary interventions in obese adolescents in improving regional and total body composition, and adds to the current literature information on the effects of different intensities of aerobic physical training in this population, suggesting that the effects in the CC are independent of training intensity for obese adolescents. This information is of significant importance and relevance, since these findings allow generalizations, since aerobic exercises can be implemented in different ways and in different places, thus broadening the options in terms of public health.

\section{CONCLUSION}

Based on the results found, it was possible to conclude that the multidisciplinary treatment with the use of aerobic training independent of the intensity in which it was performed, was sufficient to promote changes in the body composition of obese adolescents.

All authors declare no potential conflict of interest related to this article.

AUTHORS' CONTRIBUTIONS: Each author made significant individual contributions to this manuscript. PPG (0000-0002-4539706X)*, MCLP (0000-0002-8296-3024)* , MAMS $(0000-0002-2734-8416)^{*}$, and WLP $(0000-0001-5046-4522)^{*}$ were the authors who contributed to the concept and design of the research. CTCL (0000-0002-0569-0501)*, TRST (0000-0001-8443-1171)*, JPB (0000-0002-0188-9249)*, and PPG performed the bibliographical research. PPG, CTCL, and TRST were the main collaborators in the writing of the manuscript. PPG, MCLP, CTCL, JPB, and TRST performed the data collection. MAMS and WLP analyzed the data and conducted the critical analysis. All the authors reviewed and approved the final version of the work. ${ }^{*} \mathrm{ORCID}$ (Open Researcher and Contributor ID). 


\section{REFERENCES}

1. Ng M, Fleming T, Robinson M, Thomson B, Graetz N, Margono C, et al. Global, regional, and national prevalence of overweight and obesity in children and adults during 1980-2013: a systematic analysis for the Global Burden of Disease Study 2013. Lancet. 2014;384(9945):766-81.

2. Olds T, Maher C, Zumin S, Péneau S, Lioret S, Castetbon Ket al. Evidence that the prevalence of childhood overweight is plateauing: data from nine countries. Int J Pediatric Obes. 2011;6(5-6):342-60.

3. Estatística IBGE. Pesquisa de Orçamentos Familiares 2008-2009: antropometria e estado nutricional de crianças, adolescentes e adultos no Brasil. IBGE; 2010.

4. Aiello AM, Mello LM, Nunes MS, Silva AS, Nunes A. Prevalence of obesity in children and adolescents in Brazil: a meta-analysis of cross-sectional studies. Curr Pediatr Rev. 2015;11(1):36-42.

5. Siervogel RM, Demerath EW, Schubert C, Remsberg KE, Chumlea WC, Sun S, et al. Puberty and body composition. Horm Res. 2003;60(Suppl. 1):36-45.

6. Colley RC, Garriguet D, Janssen I, Wong SL, Saunders TJ, Carson V, et al. The association between accelerometer-measured patterns of sedentary time and health risk in children and youth: results from the Canadian Health Measures Survey. BMC Public Health. 2013;13(1):200.

7. Farah B, Ritti-Dias R, Balagopal P, Hill J, Prado W. Does exercise intensity affect blood pressure and heart rate in obese adolescents? A 6-month multidisciplinary randomized intervention study. Pedriatr Obes. 2014;9(2):111-20.

8. Tenório TR, Balagopal PB, Andersen LB, Ritti-Dias RM, Hill JO, Lofrano-Prado MC, et al. Effect of Low vs. High Intensity Exercise Training on Biomarkers of Inflammation and Endothelial Dysfunction in Adolescents With Obesity: A 6-Month Randomized Exercise Intervention Study. Pediatr Exerc Sci. 2018;30(1):96-105.

9. Lazzer S, Lafortuna C, Busti C, Galli R, Agosti F, Sartorio A. Effects of low-and high-intensity exercise training on body composition and substrate metabolism in obese adolescents. J endocrinol Invest. 2011;34(1):45-52

10. Buchan DS, Ollis S, Thomas NE, Buchanan N, Cooper SM, Malina RM, et al. Physical activity interventions: effects of duration and intensity. Scand J Med Sci Sports. 2011;21(6):e341-50.

11. Lee S, Bacha F, Hannon T, Kuk JL, Boesch C, Arslanian S. Effects of aerobic versus resistance exercise without caloric restriction on abdominal fat, intrahepatic lipid, and insulin sensitivity in obese adolescent boys. Diabetes. 2012;61(11):2787-95.

12. Gomes PP, Silva HJG, Lira CTC, Prado WL, Lofrano-Prado MC. Efeitos de diferentes intensidades de treinamento aeróbio sobre a composição corporal em adolescentes obesos. Rev Bras Cineantropom Desempenho Hum. 2013;15(5):594-603.

13. Tanner JM. Growth at adolescence. Oxford: Blackwell, 1962.

14. Kuczmarski RJ, Ogden CL, Grummer-Strawn LM, Flegal KM, Guo SS, Wei R, et al. CDC growth charts: United States. Adv Data. 2000;(314):1-27.

15. Lofrano-Prado MC, Hill JO, Silva HJG, Freitas CRM, Freitas SM, Ferreira MNL, et al. Reasons and Barriers to Lose Weight: Obese Adolescents' Point of View. Br J Med Med Res. 2013;3(3):474-82.
16. Kelly TL, Wilson KE, Heymsfield SB. Dual energy X-Ray absorptiometry body composition reference values from NHANES. PloS one. 2009;4(9):e7038.

17. Wasserman K. Determinants and detection of anaerobic threshold and consequences of exercise above it. Circulation. 1987;76(6 Pt 2):VI29-39.

18. Freitas CR, Gunnarsdottir T, Fidelix YL, Tenório TR, Lofrano-Prado MC, Hill JO, et al. Effects of a psychological intervention on the quality of life of obese adolescents under a multidisciplinary treatment. J Pediatr (Rio J). 2017;93(2):185-91.

19. Prado WL, Lofrano-Prado MC, Cardel M, Balagopal P, Oyama LM, Gomes PP, et al. Effect of a 12-week low vs. high intensity aerobic exercise training on appetite-regulating hormones in obese adolescents: a randomized exercise intervention study. Pediatr Exerc Sci. 2015;27(4):510-7.

20. Wong PC, Chia M, Tsou IY, Wansaicheong GK, Tan B, Wang JC, et al. Effects of a 12-week exercise training programme on aerobic fitness, body composition, blood lipids and C-reactive protein in adolescents with obesity. Ann Acad med Singapore. 2008;37(4):286-93.

21. Del Vecchio F, Galliano L, Coswig V. Aplicações do exercício intermitente de alta intensidade na síndrome metabólica. Rev Bras Ativ Fis Saúde. 2013;18(6):669-87.

22. Fedewa MV, Gist NH, Evans EM, Dishman RK. Exercise and insulin resistance in youth: a meta-analysis. Pediatrics. 2014;133(1):e163-74.

23. Nicklas BJ, Wang X, You T, Lyles MF, Demons J, Easter L, et al. Effect of exercise intensity on abdominal fat loss during calorie restriction in overweight and obese postmenopausal women: a randomized, controlled trial. Am J Clin Nutr. 2009;89(4):1043-52.

24. Cruzat VF, Donato Júnior J, Tirapegui J, Schneider CD. Hormônio do crescimento e exercício físico: considerações atuais. Rev Bras Cienc Farm. 2008;44(4):549-62

25. Waters E, Summerbell CD, Edmunds LD, Kelly S, Brown T, Campbell KJ. Interventions for preventing obesity in children. Cochrane Database Syst Rev. 2005;(3):CD001871.

26. Malina RM. Secular trends in growth, maturation and physical performance: a review. Anthropol Rev 2004;67:3-31.

27. Benítez-Porres J, Alvero-Cruz JR, Albornoz MC, Correas-Gómez L, Barrera-Expósito J, Dorado-Guzmán $\mathrm{M}$, et al. The Influence of 2-Year Changes in Physical Activity, Maturation, and Nutrition on Adiposity in Adolescent Youth. PloS one. 2016;11(9):e0162395.

28. Hauspie R, Roelants M. Adolescent Growth. In: Cameron N, Bogin B, editors. Human Growth and development. London: Academic Press; 2012. p. 57-80.

29. Andrade MLSS, Silva HJG, Lofrano-Prado MC, Ferreira MNL, Lins TA, Costi RB, et al. Efeitos da intervenção multidisciplinar sobre a ingestão alimentar em adolescentes obesos. ConScientiae Saúde. 2012;11 (2):289-95.

30. Lofrano-Prado MC, Hill JO, Silva HJG, Freitas CRM, Lopes-de-Souza S, Lins TA, et al. Acute effects of aerobic exercise on mood and hunger feelings in male obese adolescents: a crossover study. Int $J$ Behav Nutr Phys Act. 2012;9(1):38. 